\title{
Structure and properties of polymer composite based on natural zeolite
}

\author{
Liubov I. Melnyk, Lev P. Chernyak, Valentin A. Sviderskyy, Oleg Yu. Belousov, \\ Alexander V. Nehreyko \\ National Technical University of Ukraine "Igor Sikorsky Kyiv Polytechnic Institute", \\ 37 Peremohy Ave., Kyiv 03056, Ukraine \\ lubaxtkm@ukr.net
}

Keywords: polymer composite, filler, zeolite, pore structure, properties.

This research paper is dedicated to the possibility of expanding directions and increasing the use of natural zeolite as filler $(65-85 \%)$ for the manufacture of composite material. The structure of composites with varieties of copolymers (Styrene- butadiene, Styrene-acrylate) and revealed the features of the structure (open porosity $5-24 \%$ ) and material properties of the zeolite concentration are identified.

\section{Introduction}

Composite materials are marked by the constant expansion of the fields of practical use [1]. The main criteria for the selection of composite material are mechanical, thermal and electrical characteristics, which determine the efficiency of use in various fields of science, technology and industry.

The predetermined characteristics of the composites are achieved by varying different types of starting materials that should serve as filler or reinforcing component and matrix or binder. Hence, there is an inextricable link between the development of the raw material base of production, the properties and the variety of composites.

The possibility of expanding the variety of composite materials when involved in their production of natural zeolite determine the relevance of this research.
Literature data analysis and problem statement

Polymeric composite materials have become widespread [2-6]. In this case, the polymer matrix depends on the heat and moisture resistance, resistance to corrosive environment, dielectric properties and operating temperature of the composite.

The filler makes the composite material strong, rigid, stable properties in a certain temperature range. Moreover, when it is used as filler of raw materials of different genesis, it is possible to comprehensively address the quality issues of composites and ecology by increasing the efficiency of use of natural raw materials.

In this regard, zeolite [7, 8], which is considered as a possible filler of polymer composites [9-11], attracts attention among natural raw materials. 
It is known that zeolites are characterized by their developed pores of molecular size, which have homogeneous channels and cavities, and create a large specific surface area. In addition to the structural features, it is also important to distribute large reserves of natural zeolite, including in Ukraine.

Developments for the use of new varieties of raw materials, including zeolites, need to consider the features of its physical and chemical composition, the impact on the structure and characteristics of the systems under investigation and the properties of the manufactured products.

\section{Experimental part}

\section{Material and methods}

The subject of the research was composite materials based on a copolymer system called natural zeolite.

The work methods involved the combination of physical and chemical methods of raw material analysis and its composites with technological testing of material properties:

- analysis of the chemical composition of raw materials by standard methods;

- X-ray phase analysis (powder mount) using the DRON-3M diffraction meter $(\mathrm{Cu} \mathrm{K} \alpha$ 1-2 emission, $40 \mathrm{kV}$ pressure, $20 \mathrm{~mA}$ current, $2 \mathrm{deg} / \mathrm{h}$ speed);

- analysis of the material structure using raster electronic microscope JSM 6060.

The technology of composite production based on the copolymer-filler system consisted of sequential execution of the following operations:
- mechanical activation of the filler and binder in a ball mill (20 minutes);

- maturation of the composition (48 hours at room temperature);

- preshaping (dosing of batch weights of $5.0 \mathrm{~g}$ and laying them in forms);

- heat treatment (radual temperature rise and holding for 1 hour at 80 degrees Celsius);

- pressing of composite material (10 MPa pressure).

The samples obtained were in the form of a cylinder with a diameter of $16 \mathrm{~mm}$; the sample density was $1.4-1.7 \mathrm{~g} / \mathrm{cm}^{3}$.

Taking into account the lack of standardized methods for determination of porosity, water absorption of filled polymer composite materials, we adopted the method for determining these parameters for concrete in accordance with DSTU B.V.2.7-170: 2008.

The ability of the samples to resist abrasion was determined in accordance with DSTU B.V.2.7-212: 2009 on the Beme abrasive disc.

Mechanical properties, including compression strength test were performed on a TIRAtest-2151 test machine [12].

The aqueous styrene-butadiene brand Latex 2012 (Fig. 1), and styrene-acrylic dispersion of Latex R 161 E, Latex DC 640 (Fig. 2) were used as the copolymer (Table $\mathbf{1}$ ).

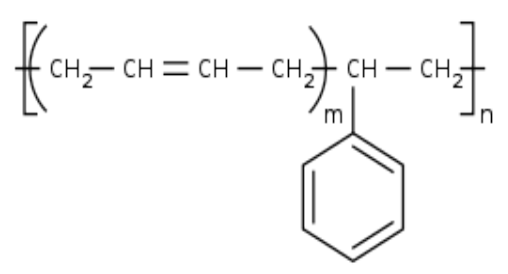

Figure 1. Structural formula styrene-butadiene dispersion 
Table 2. Chemical composition of the filler

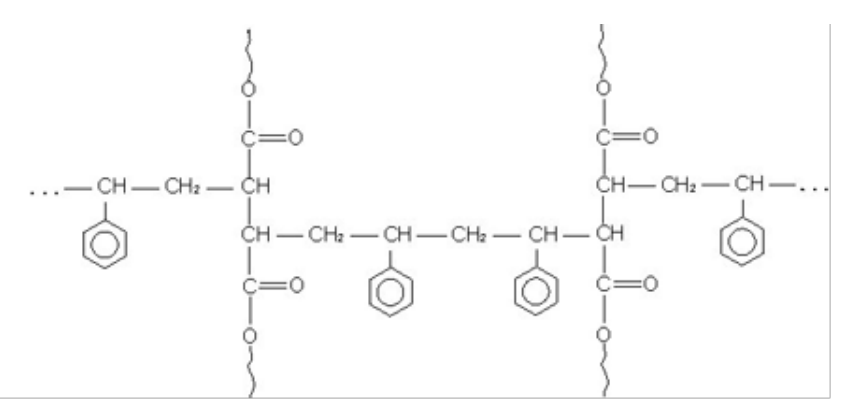

Figure 2. Structural formula styrene-acrylic dispersion

Table 1. Characteristics of co-polymers

\begin{tabular}{|l|c|c|c|}
\hline \multirow{2}{*}{ Indicators } & \multicolumn{3}{|c|}{ Type of co-polymers } \\
\cline { 2 - 4 } & $\begin{array}{c}\text { Latex } \\
2012\end{array}$ & $\begin{array}{c}\text { Latex } \\
\text { R 161 E }\end{array}$ & $\begin{array}{l}\text { Latex } \\
\text { DC } 640\end{array}$ \\
\hline $\begin{array}{l}\text { hysical } \\
\text { appearance } \\
\text { dispersion } \\
\text { of white } \\
\text { color }\end{array}$ & $\begin{array}{c}\text { Aqueous } \\
\text { dispersion } \\
\text { of white } \\
\text { color }\end{array}$ & $\begin{array}{c}\text { Aqueous } \\
\text { dispersion } \\
\text { of white } \\
\text { color }\end{array}$ \\
\hline $\begin{array}{l}\text { Amount of } \\
\text { solids, \% }\end{array}$ & $51.0 \%$ & $56.0 \%$ & $40.0 \%$ \\
\hline pH & 5.5 & 8.0 & 8.5 \\
\hline $\begin{array}{l}\text { Viscosity, } \\
\text { MPa•s }\end{array}$ & 200 & $\begin{array}{l}200- \\
1200\end{array}$ & 20 \\
\hline $\begin{array}{l}\text { Temperature } \\
\text { (MTPU), }{ }^{\circ} \mathrm{C}\end{array}$ & $<5$ & $<1$ & $<5$ \\
\hline $\begin{array}{l}\text { Chemical } \\
\text { composition }\end{array}$ & $\begin{array}{c}\text { Styrene- } \\
\text { butadiene }\end{array}$ & $\begin{array}{c}\text { Styrene- } \\
\text { acrylate }\end{array}$ & $\begin{array}{c}\text { Styrene- } \\
\text { acrylate }\end{array}$ \\
\hline $\begin{array}{l}\text { Amount of } \\
\text { styrene, \% }\end{array}$ & - & 30 & 50 \\
\hline $\begin{array}{l}\text { Amount of } \\
\text { acrylate, \% }\end{array}$ & - & 70 & 50 \\
\hline $\begin{array}{l}\text { Size of } \\
\text { particles, nm }\end{array}$ & 140 & 160 & 50 \\
\hline
\end{tabular}

The natural zeolite of the Sokirnytsia mineral deposit in the Zakarpatska region was used as fillers.

The chemical composition of the natural zeolite is characterized by a high content of $\mathrm{SiO} 2$ at a quantitative ratio of $\mathrm{SiO} 2: \mathrm{Al} 2 \mathrm{O} 3=5.2: 1$ (Table 2).

\begin{tabular}{|c|c|c|c|c|c|c|c|c|c|}
\hline \multirow{2}{*}{$\begin{array}{c}\text { Sample } \\
\text { name }\end{array}$} & \multicolumn{7}{|c|}{ Content of oxides, \% } \\
\cline { 2 - 10 } & $\mathrm{SiO}_{2}$ & $\mathrm{Al}_{2} \mathrm{O}_{3}$ & $\mathrm{Fe}_{2} \mathrm{O}_{3}$ & $\mathrm{TiO}_{2}$ & $\mathrm{CaO}$ & $\mathrm{MgO}$ & $\mathrm{Na}_{2} \mathrm{O}$ & $\mathrm{K}_{2} \mathrm{O}$ & loi \\
\hline Zeolite & 68.02 & 13.04 & 1.92 & 0.30 & 2.71 & 1.63 & 1.57 & 2.64 & 16.94 \\
\hline
\end{tabular}

Analysis of the mineral composition of the investigated raw material showed that the zeolite includes (by weight, \%): clinoptilolite 6580 , montmorillonite $2-4$, quartz up to 10 , plagioclase 5-10, carbonate 3, hydromica 1-3 (Fig. 3).

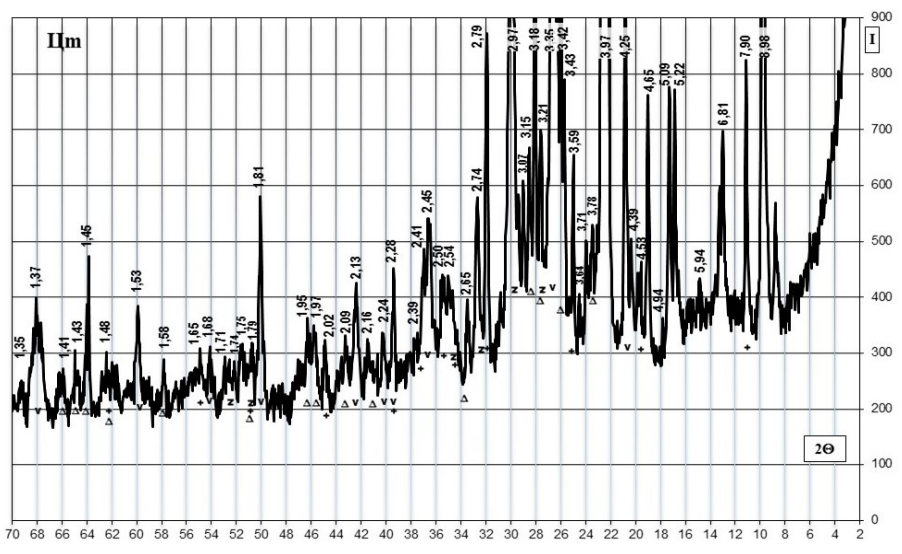

Figure 3. X-ray diffraction of zeolite:

$\mathrm{z}$ - zeolite, $\mathrm{v}$ - quartz, + - kaolinite, $\Delta$ - feldspar

A number of systems with different copolymers have been investigated as binders in differentiating the zeolite concentration as filler (Table 3).

Table 3. Composition of the composites

\begin{tabular}{|c|c|c|c|}
\hline \multirow{2}{*}{$\begin{array}{c}\text { Amount of } \\
\text { zeolite, mass. } \\
\%\end{array}$} & \multicolumn{3}{|c|}{ Type of co-polymers and code of } \\
samples \\
\cline { 2 - 4 } & $\begin{array}{c}\text { Latex } \\
2012\end{array}$ & $\begin{array}{c}\text { Latex } \\
\text { R 161 E }\end{array}$ & $\begin{array}{c}\text { Latex } \\
\text { DC 640 }\end{array}$ \\
\hline 65 & 1 & 5 & 9 \\
\hline 75 & 2 & 6 & 10 \\
\hline 85 & 3 & 7 & 11 \\
\hline
\end{tabular}




\section{Results and discussion}

According to the experimental data, it was found that the composites based on the studied systems are significantly different in pore structure and properties (Table 4).

Table 4. Structure and properties of composite based on system copolymer - zeolite

\begin{tabular}{|c|c|c|c|c|c|c|}
\hline \multirow[t]{3}{*}{ Properties } & \multicolumn{6}{|c|}{$\begin{array}{l}\text { Brand of copolymer, } \\
\text { content of zeolite }(\%)\end{array}$} \\
\hline & \multicolumn{2}{|c|}{$\begin{array}{l}\text { Latex } \\
2012\end{array}$} & \multicolumn{2}{|c|}{$\begin{array}{l}\text { Latex } \\
\text { R } 161 \mathrm{E}\end{array}$} & \multicolumn{2}{|c|}{$\begin{array}{l}\text { Latex } \\
\text { DC } 640\end{array}$} \\
\hline & 65 & 85 & 65 & 85 & 65 & 85 \\
\hline $\begin{array}{l}\text { Average } \\
\text { density, } \\
\mathrm{g} / \mathrm{sm}^{3}\end{array}$ & $\stackrel{+}{\text { m? }}$ & $\underset{n}{6}$ & $\stackrel{n}{n}$ & જ઼ & $\stackrel{\infty}{\stackrel{\infty}{\sim}}$ & $\underset{-}{\sigma}$ \\
\hline $\begin{array}{l}\text { Water } \\
\text { absorption, } \\
\% \text {, after } 24 \mathrm{~h} \text {. }\end{array}$ & $\frac{\infty}{m}$ & $\begin{array}{c}\stackrel{0}{-} \\
\infty\end{array}$ & $\begin{array}{r}\text { f } \\
\dot{\nabla}\end{array}$ & $\underset{\forall}{\sigma}$ & $\underset{\sim}{\infty}$ & $\stackrel{\sim}{\sim}$ \\
\hline $\begin{array}{l}\text { Resistance to } \\
\text { abrasion, } \\
\mathrm{g} / \mathrm{sm}^{2}\end{array}$ & $\stackrel{n}{8}$ & $\begin{array}{l}2 \\
0 \\
0\end{array}$ & $\begin{array}{l}n \\
0 \\
0\end{array}$ & $\stackrel{n}{a}$ & 응 & $\frac{n}{0}$ \\
\hline $\begin{array}{l}\text { Modulus of } \\
\text { elasticity, } \\
\mathrm{Pa} / \mathrm{mm}^{2}\end{array}$ & $\begin{array}{l}\stackrel{\infty}{+} \\
\dot{f}\end{array}$ & $\begin{array}{l}\infty \\
\stackrel{0}{\rho}\end{array}$ & $\begin{array}{l}\infty \\
\stackrel{\nabla}{ }\end{array}$ & 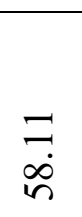 & 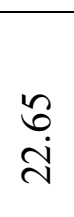 & $\begin{array}{l}6 \\
6 \\
6\end{array}$ \\
\hline $\begin{array}{l}\text { Open } \\
\text { porosity, \% }\end{array}$ & テे & ָ̃ & $\begin{array}{l}\text { ڤ } \\
\text { ‡े }\end{array}$ & $\begin{array}{l}\text { ָે } \\
\text { İ }\end{array}$ & $\begin{array}{l}\tilde{m} \\
\ddot{n}\end{array}$ & 命 \\
\hline $\begin{array}{l}\text { Specific part } \\
\text { of open pores }\end{array}$ & $\stackrel{+}{\stackrel{\sim}{0}}$ & $\begin{array}{l}\infty \\
\infty \\
0\end{array}$ & $\stackrel{\Xi}{\overrightarrow{0}}$ & $\ddot{n}$ & $\begin{array}{l}\infty \\
0 \\
\dot{0}\end{array}$ & $\begin{array}{l}\text { OD. } \\
0 \\
0\end{array}$ \\
\hline
\end{tabular}

The total porosity and development of its varieties depend on the type of polymeric binder. Thus, in the equal period of the filler concentration changes $\mathrm{Cz}=65-85$ wt. $\%$ using Latex 2012 it showed the total porosity at the level of 25.9-39.8\%; using Latex R $161 \mathrm{E}$ it is equal to 24.1-35.8\%, and using Latex DC 640 the total porosity is at the level of 19.2-33.5\%.

The difference in the development and ratio of different type of porosity are as follows. When the filler concentration changes from 65 to $85 \mathrm{wt}$. $\%$, the composite samples based on the zeolite Latex 2012 system are characterized by an increase in the number of open pores from 9.5 to $22.7 \%$, at the same time, their actual weight in the total porosity increases from 0.24 to 0.88 .

Composite samples based on the zeolite system Latex R 161 E are characterized by an increase in the number of open pores from 5.0 to $12.2 \%$ with their actual weight in the total porosity increasing from 0.14 to 0.51 .

Composite samples based on the zeolite system Latex DC 640 show a decrease in the number of open pores from 23.3 to $16.0 \%$; however, their actual weight in the total porosity increases from 0.68 to 0.83 .

Therefore, in the research interval of $\mathrm{Cz}=65$ 85 wt. \% the composite based on the zeolite system Latex R 161 E is characterized by the lowest development of open pores. The highest development of open pores at $\mathrm{Cz}=65 \mathrm{wt}$. \% is characterized by a composite based on the zeolite system Latex DC 640 (23.3\%), and composite based on zeolite system Latex 2012 (22.7\%) at Cz $=85$ wt. $\%$.

The results of scanning electron microscopy (Fig. 4) became a clear confirmation of these features of the pore structure of the composites based on the researched systems. 

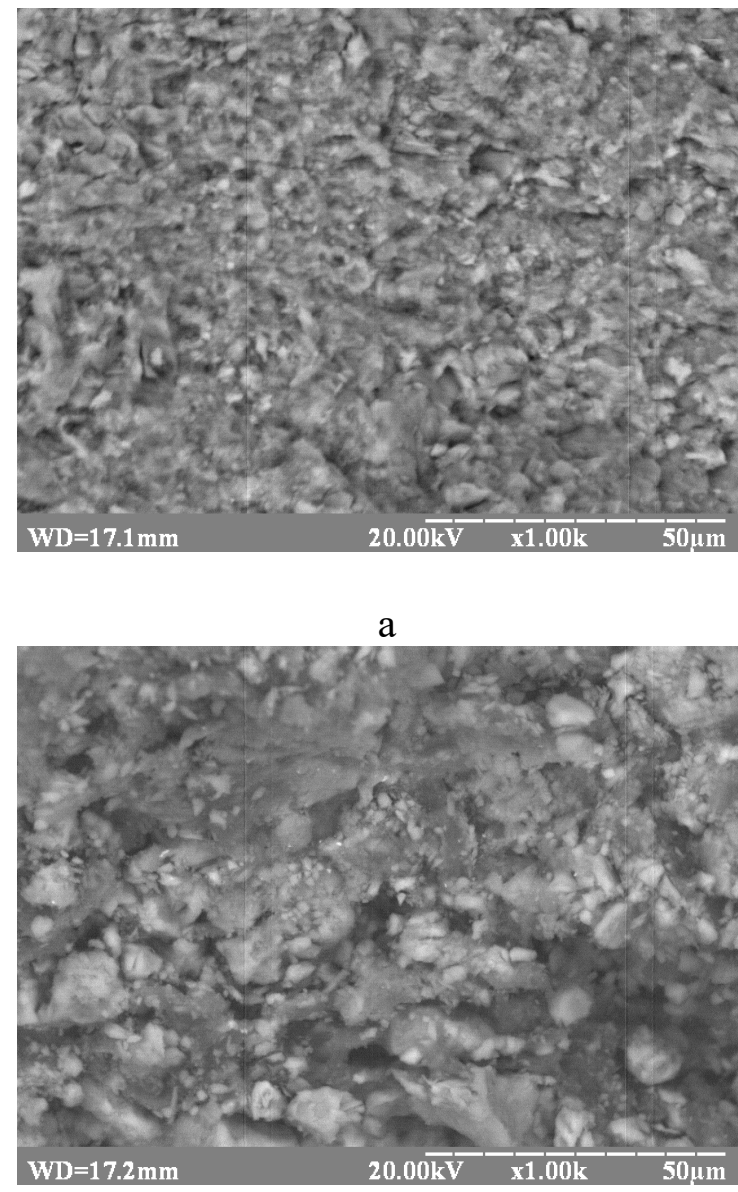

b

Figure 4. Scanning electron microscopic images of the pore structure of composites based on the zeoliteLatex 2012 system: $\mathrm{a}-\mathrm{C}_{\mathrm{z}}=65 \%$, x 1000; b - $\mathrm{C}_{\mathrm{z}}=85 \%$, $\mathrm{x} 1000$

Along with the features of the composite structure based on the studied systems, there are differences in their properties.

As for the maximum water absorption (Fig. 5), there is a gradual increase in water absorption from 5.13 to $9.12 \%$ with an increase in open porosity from 9.5 to $22.7 \%$ increasing zeolite content from 65 to 85 wt. \% using the Latex 2012 copolymer system; these notions have acknowledged representation.

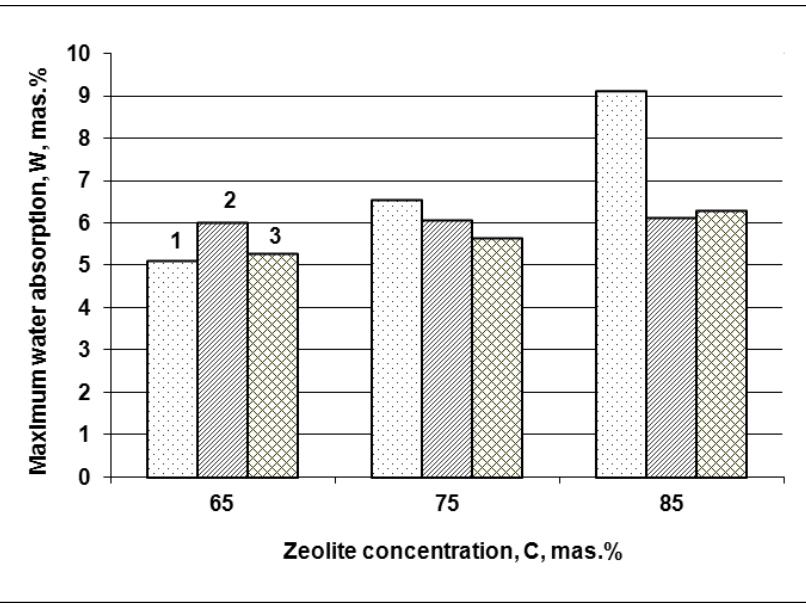

Figure 5. Dependence of maximum water absorption from zeolite concentration for copolymer systems: 1 - Latex 2012; 2 - Latex R-161; 3 - Latex DC-640.

For the copolymer system with the Latex R-161 E, the maximum water absorption is registered at $5.42-6.13 \%$ with an increase in open porosity from 5.0 to $12.2 \%$, and with the Latex DC-640 there is a slight increase in the maximum water absorption from 5.28 to $6.32 \%$ while reducing the open porosity from 23.3 to $16.0 \%$.

Using the same type of filler such as natural Sokyrnytsya zeolite and its same granulometry, these fluctuations in changes in water absorption may be related to the characteristics of the surface properties and hydrophilic properties of the copolymer species and their degree of adhesion to the zeolite.

Increasing the geometric density of composite samples with growing zeolite concentration from 65 to $85 \%$ in systems with Latex 2012 and Latex DC-640 corresponds to a decrease in overall porosity.

The elastic coefficient indicates the dependence of the composite strength on both the 
zeolite concentration and the copolymer variety (Fig. 6).

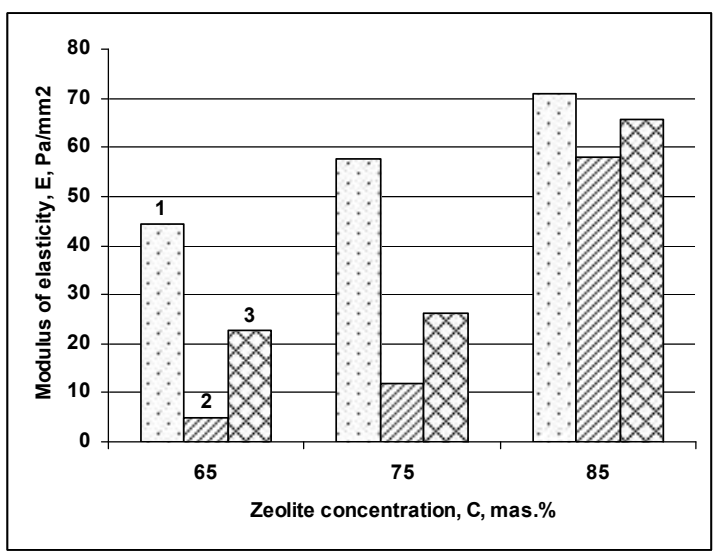

Figure 6. Dependence of the elastic coefficient of the composite from zeolite concentration for copolymer systems: 1 - Latex 2012; 2 - Latex R-161; 3 - Latex DC640.

The factors of the filler content and the variety of copolymers have a much less effect on the wearing of the composite samples, which show generally insignificant indicators.

\section{Conclusions}

1. The possibility of making composite materials using natural zeolite as filler with the amount 65-85 wt.\% along with different types of copolymers as binders is showed. The peculiarities of the pore structure and properties of the composites while differentiating the zeolite concentration and polymeric binders are determined.

2. The characteristics of the pore structure of the investigated composites depend on the concentration of the filler and the variety of copolymer. In the concentration range of zeolite $\mathrm{Cz}=65-85$ wt.\% the proportion of open pores is 0.14-0.51 for Latex R $161 \mathrm{E}$; $0.24-0.88$ for Latex 2012 and 0.68-0.83 for Latex DC 640.
3. Concentration variety of zeolite and different types of the copolymer allows you to adjust the parameters of the physical, mechanical and operational properties of the composites within the following limits: density 1.34-1.69 $\mathrm{g} / \mathrm{cm}^{3}$, maximum water absorption 5.13-9.12\%, elastic coefficient 26.2-71,0 Pa/mm², wearing capacity $0.05-0.025 \mathrm{~g} / \mathrm{cm}^{2}$. This defines the perspective of practical use of such composites as facing, lining, filtering materials, etc.

\section{References}

[1] Chung Deborah D. L. Composite Materials. Science and Applications 2nd Edition. N.Y.: Springer; 2010 .

[2] Kerber M.L., Vinogradov V.M., Golovkin G.S.; Berlin A.A. Polymer composite materials. Structure. Properties. Technology.SPb: Professyya; 2011.

[3] Melnyk, L. Research of electrical properties of epoxy composite with carbon fillers. Technology audit and production reserves. 2017; 3/1(35): 4-10.

[4] Suprakas, Sinha Ray, Masami, Okamoto. Polymer/layered silicate nanocomposites: a review from preparation to processing. Progress in Polymer Science. 2003; 28: 1539-1641.

[5] Sokolov, I.I., Troshkin, I.V. Effect of the Chemical Nature of Fabric Mineral Fillers on the Properties of Polymer Composite Materials. Glass and Ceramics. 2016; 73 (5-6): 231-233.

[6] Rothon R.N. Particulate fillers for polymers. Rapra Rev. Rep. 2001; 12: 16-17.

[7] Narayanan S. A., Batchelor W., Webley P. Review on the use of zeolites to create valuable paper products and paper-like adsorbent materials. Appita Journal. 2013; 66(3): 235-245.

[8] Mumpton Frederick A. Mineralogy and Geology of the Natural Zeolites. Mineralogical Society of America Reviews in Mineralogy. 1977; 4. 
[9] Al-ghamdi A. M. S., Mark J. E. Zeolites as reinforcing fillers in an elastomer. Polymer Bulletin. 1988; 20 (6): 537-542.

[10] Zaharri N., Othman N. Optimization of Zeolite as Filler in Polypropylene Composite. Journal of Reinforced Plastics and Composites. 2009; 29(14):2211-

2226 https://doi.org/10.1177/0731684409347593

[11] Sandomierski M., Okulus Z., Voelkel A. Active diazonium-modified zeolite fillers for methacrylatebased composites. Composite Interfaces. 2019; 26(7): 643657.

[12] Shydlovskyy M. S., Shpak D. YU., Tymoshenko O. V. New Materials: Methodical instructions for performing laboratory works "Testing equipment for structural plastics and rubber under short-term load". Kiev: NTUU "KPI"; 2012.

http://ela.kpi.ua/handle/123456789/1542 